Article

\title{
Greenhouse Gas Assessment and Compensation on Brazilian Low Volume Rural Roads Using CarbonROAD_The Santa Rosa de Lima Case
}

\author{
Reus Salini ${ }^{1, *}$, Carl Anders Lenngren ${ }^{2}$, Lauro Bassi ${ }^{3}$ and Dalcio Pickler Baesso ${ }^{4}$ \\ 1 Neogennium Technologies, Rua Adhemar da Silva, 826, Florianópolis, SC 88101-090, Brazil \\ 2 Department of Traffic and Roads, Lund University, Box 118, Lund 221 00, Sweden; \\ E-Mail: carl.lenngren@tft.lth.se \\ 3 Environmental Consultant, Rua Saldanha da Gama, 225, Canoas, RS 92310-630, Brazil; \\ E-Mail: laurobassi@gmail.com \\ 4 Santa Catarina State Department of Transportation, Rua Tenente Silveira, 162, \\ Florianópolis 88010-300, Brazil; E-Mail: dalcio@deinfra.sc.gov.br \\ * Author to whom correspondence should be addressed; E-Mail: R.Salini@gmx.net; \\ Tel.: +48-9961-9919.
}

Academic Editor: Yu-Pin Lin

Received: 6 May 2015 / Accepted: 13 October 2015 / Published: 23 October 2015

\begin{abstract}
The "Santa Catarina Rural" is a Program co-funded by The World Bank for improvements on $1300 \mathrm{~km}$ of low volume rural roads on Southern Brazil. The pioneer project under the program was on the municipality of Santa Rosa de Lima, where the greenhouse gas (GHG) emissions resulting from the road improvement activities as well as the regular traffic were assessed on an experimental basis using the CarbonROAD software application. Here, we show details of the CarbonROAD software application and the construction emissions assessment procedure as well as the mitigating effect of the plants used for compensation. It was found that most of the emissions come from the road improvement work. This includes earthworks, fuel for motor graders, bulldozers and other machines, and materials and gravel extraction, industrialization and transportation, etc. Only a smaller portion comprises regular road traffic. The accumulated emission balance shows that the carbon absorption is larger than construction emissions after just 15 months. The potential for price appraisal of the generated carbon credits is explored.
\end{abstract}


Keywords: carbon emission, rural roads, compensation

\section{Introduction}

The "Santa Catarina Rural", a program co-funded by The World Bank is currently being pursued in Southern Brazil. The scope is to improve about $1300 \mathrm{~km}$ of low volume rural roads with the support of farmers in the area.

A new experimental design method was developed as existing simplified engineering procedures were not suitable for the present project. It is focused on the municipality of Santa Rosa de Lima, a small rural town $120 \mathrm{~km}$ from Florianópolis with around 2000 habitants. Most of them have a German heritage. The economy is based on organic vegetables and milk production, and country tourism. The road project comprises of improvements of 12 roads, with a total length of $14.85 \mathrm{~km}$, to facilitate the production transportation as well as the access for tourists. The key information used for this study, such as traffic and work activities, was taken from the engineering plans and studies.

As part of the experimental design method, we performed a greenhouse gas (GHG) assessment for the emissions related to the road works by using the software CarbonROAD. It calculates all emissions from the construction per se, and that from maintenance activities and traffic as well.

In addition, the project includes the mitigation of GHG by selected suitable vegetation planted for this purpose. The idea is to calculate a compensation for the emissions caused by the road work and further traffic.

\section{Developing a Mathematical Model for GHG Assessment}

One of main challenges to launch software for the emission assessment is the development of a solid mathematical model to calculate the emissions for each maintenance or road construction activity. For the CarbonROAD development, a substantial number of sources and published researches were evaluated and considered. The Environmental Protection Agency (EPA) published standards for gasoline and diesel emissions [1], including the carbon dioxide itself as well as equivalent greenhouse gases, like methane and nitrous oxide; this information together with the fuel consumption per kilometer or per hour allows for the calculation of the emission for a large number of vehicles and machinery activities. Chehovits and Galehouse [2] did some interesting research around the emissions from hot and cold asphalt concrete production, asphalt emulsion industrialization and production, pavement layer construction, pavement recycling, Portland cement concrete production and pavement layer construction and aggregate production, among other items. The emissions for many different pavement materials were also subject of a study made by Chappat and Bilal [3]. The fact is that the data published by different sources may have large differences on the reported emissions, due to the different methodologies used for the assessments and other factors.

The lack of an official and standardized methodology, with normalized values is a gap that must to be filled. In 2013, the Swedish Construction sector started an initiative to develop a standard for reporting of $\mathrm{CO}_{2}$ in civil engineering projects. Among the goals is to create an Environmental Product Declaration (EPD) according to EN 15804 standard, based on the product life cycle assessment (LCA) 
and product category rules (PCR). The embodied carbon is one of the main aspects for LCA; other factors are acidification, toxicity and stratospheric ozone depletion, among others.

According Miljöstyrningsrådet, The Swedish Environmental Management Council [4], the organization which maintains EPD-System in Sweden, the EPD declaration may have many uses, like:

- Tenders, e.g., "higher" value of $\mathrm{CO}_{2}$ optimized projects;

- Reporting, e.g., compare two projects;

- Internal environmental work, e.g., key parameters for each project, to set a project located goal to minimize $\mathrm{CO}_{2}$;

- Marketing, e.g., $\mathrm{CO}_{2}$ optimized projects;

- Assist purchasers and users to make informed comparisons between products;

- Encourage improvement of environmental performance; and,

- Provide information for assessing the environmental aspects of products over their life cycle.

According to the Swedish Construction companies [5] the expected results for the initiative are:

- Developing of a verification procedure to issue EPD/climate declaration for infrastructural projects according to Trafikverket's (Transport Administration) PCR. The EPD will be used in the public procurement to choose the best offer by Trafikverket;

- Scanning of practical limitations for the climate declaration, technical requirements to LCA software, LCA methodology, using of the verified LCA databases, general/project specific data, etc.;

- Recommendation on how to stimulate the contractors and the sub-contractors to minimize and report $\mathrm{CO}_{2}$ in the infrastructural projects;

- How to integrate GHG/Carbon Footprint reporting system on the company level with the $\mathrm{CO}_{2}$ reporting system by EPD on the building project level.

\section{CarbonROAD, the GHG Emission Assessment Tool for Roads}

The CarbonROAD is a software application developed in Sweden with the first version 1.0 released in 2012. Its objective is to provide a robust, quick and convenient way to estimate the GHG emission for most work related to highway and infrastructure construction as well as to the further traffic operation.

The implementation of the mathematical model in the software required as much as 23 thousand lines of source code (Delphi language). An artificial voice is being used to facilitate the experience for the user and remind them of important aspects. The Figures 1 and 2 show two sample screens.

CarbonROAD version 1.0 is able to assess the emissions due the material extraction at quarries or production, transportation and layer construction or whatever application performed, among others, for the following services and activities:

- Asphalt concrete, including hot and cold mixed, dense or open graded;

- Bituminous macadam, both, hot and cold mixed;

- Portland cement concrete;

- Sand-asphalt mixtures, hot and cold;

- Unbounded base and sub-base granular layers;

- Soil or stone reinforcement layers;

- Earthworks, including soils and stones, fillings and stockpile; 
- Use of water for general purposes;

- Usage of diluted asphalt and asphalt emulsions for general purposes, including priming/sealing and layer bonding;

- Existing pavement milling and stockpiling;

- Cold and hot pavement recycling, in-situ and off-site;

- Site preparation, vegetation removal and sanitization;

- Drainage;

- Bridges and related construction activities;

- Usage of vehicles and machinery for general purposes, including trucks of many sizes, off-road trucks, scrapers, bulldozers, motor grader, compactors of many types, excavator, tankers trucks of many sizes, cranes of different sizes, wheeled or tracked tractors, loaders, sweepers, patching specialized trucks, wheeled or tracked ultra-compact machinery ("Bob-Cat" like), cars and vans running diesel, gasoline or ethanol, buses of many sizes, and a set of full customizable vehicles or machinery;

- Goods transportation by train or boat;

- Traffic emission on regular road operation.

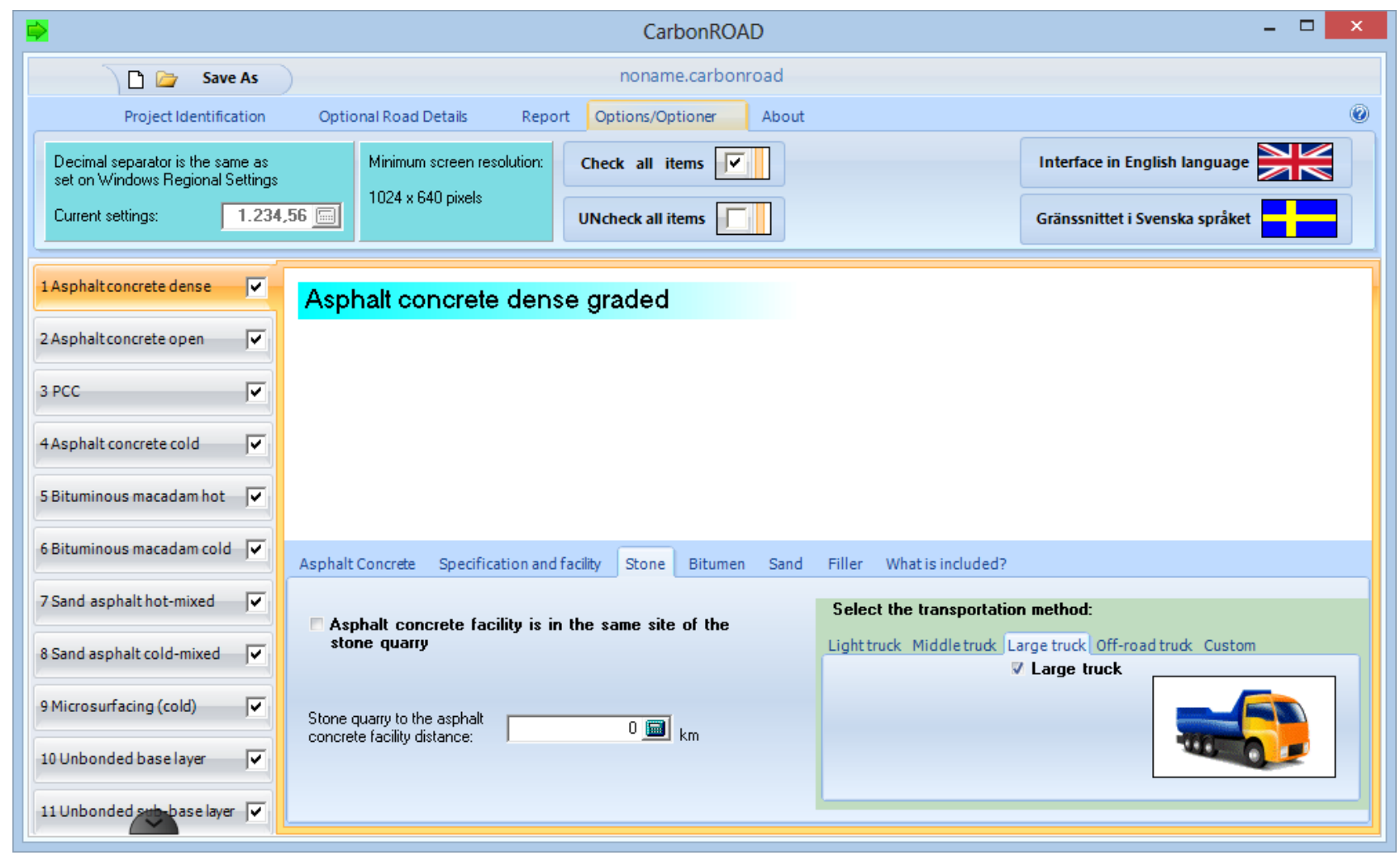

Figure 1. Screen to fill up the input data for calculation. 


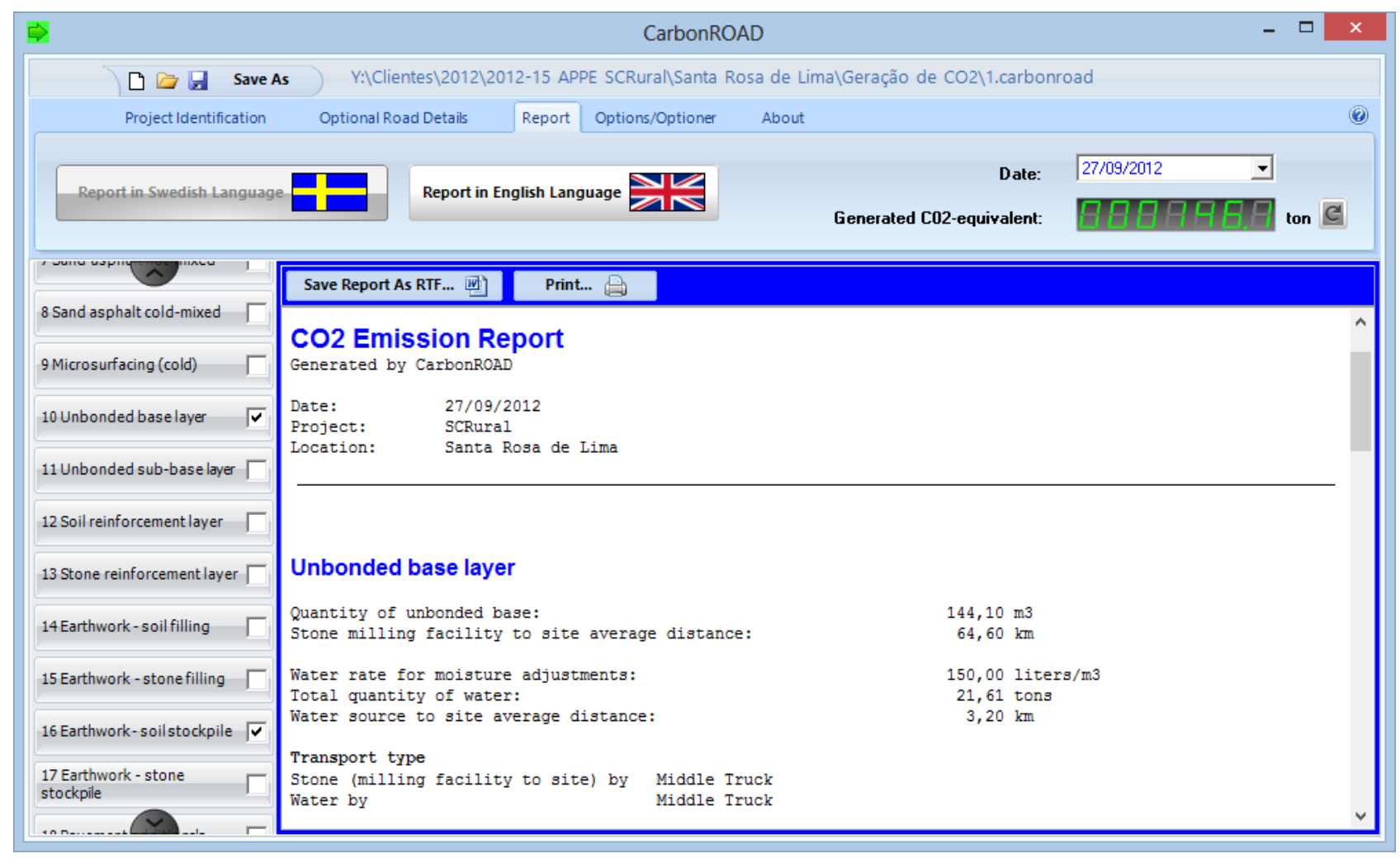

Figure 2. CarbonROAD report.

A large part of the emissions on road construction is related to transporting materials. To improve the accuracy of the calculation, the CarbonROAD software allows to choose the size of the used truck among light, middle or large truck, or off-road truck and scraper, when appropriate, for all activities that transport is required; in addition, the user has the option to enter a customized truck, by filling the diesel consumption and load capacity, as shown on Figure 3.

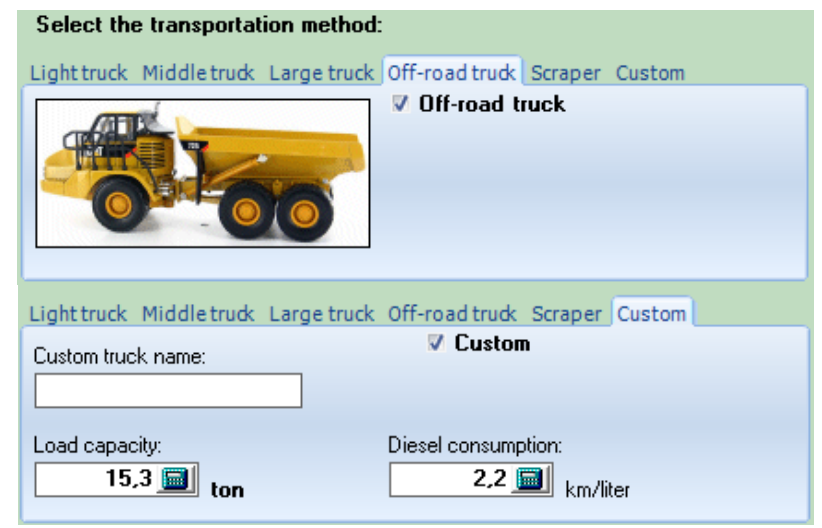

Figure 3. Transportation method selection.

\section{Calculating the Emission for Santa Rosa de Lima, Brazil}

CarbonROAD is used for important projects. One of the first was on a small project for improvements of roads at the municipality of Santa Rosa de Lima, Brazil. The project includes 12 segments of low 
volume rural roads with a total of $14.85 \mathrm{~km}$. The roads are used basically for organic vegetables and milk production transport, and for rural tourism. It is the first project of the "Santa Catarina Rural" Program.

The main improvements include road geometry changes, especially curves and grades rectifications, construction of a new and improved drainage system, interlocking concrete pavement on critical points and gravel/grit on all the length, with a total of 500 interventions, an average of one intervention every $30 \mathrm{~m}$. Figure 4 shows one segment of such road when the team was checking the required length for a culvert.

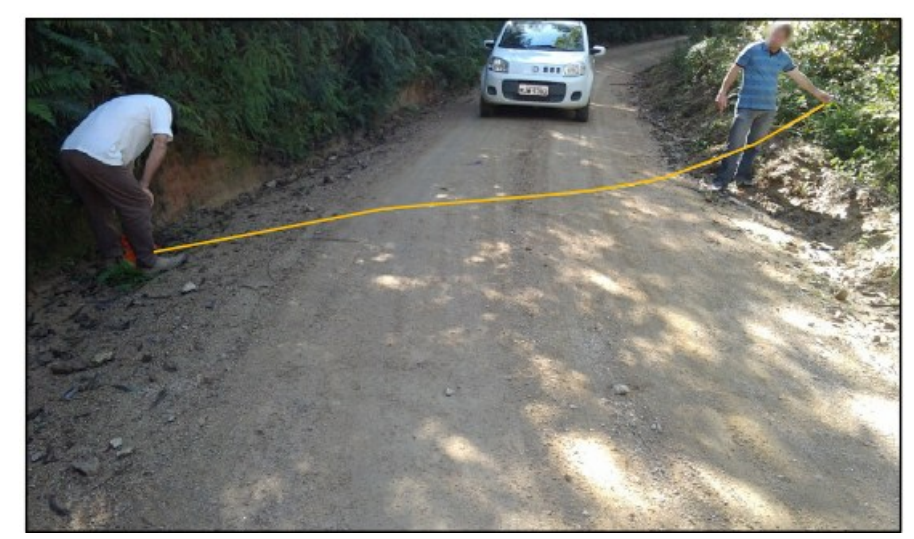

Figure 4. Checking the required length for a culvert.

Table 1 shows the calculation result, including the activities or services and its quantities, generated $\mathrm{CO}_{2}$-Equivalent as well as the description of what is included on the calculation. Figure 5 is showing the sub-totals, according to the activity. An important number of bus trips to transport the personnel from the base camp to the working places on the roads, and back, every day, are required and its emissions were included.

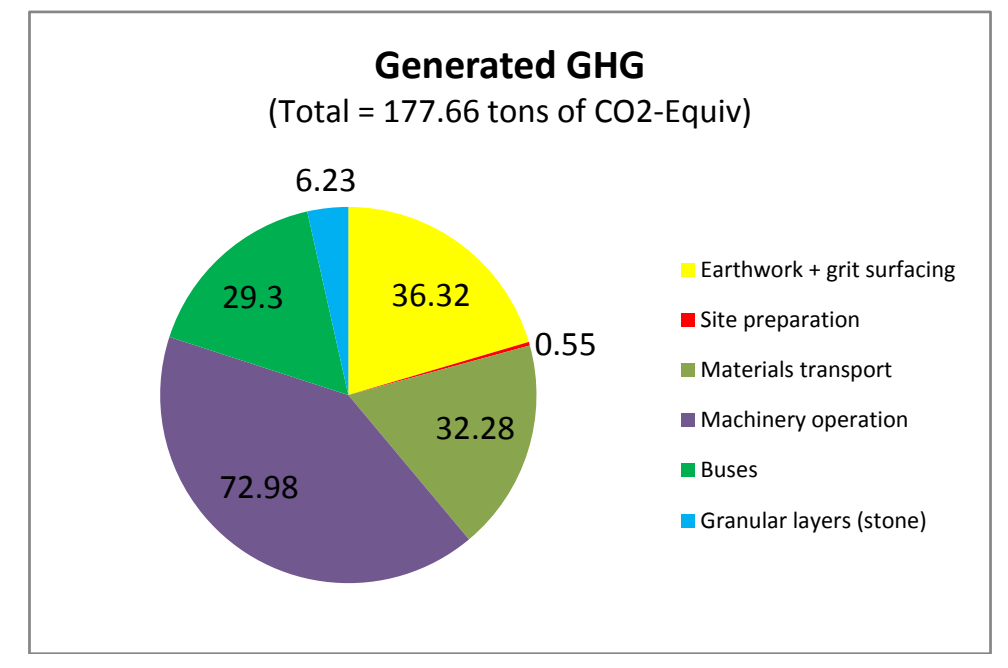

Figure 5. Generated greenhouse gas (GHG) according to the group of activities. 
Table 1. Total GHG emission generated on Santa Rosa de Lima Project.

\begin{tabular}{|c|c|c|c|}
\hline Activity or Service & Quantity & $\begin{array}{c}\text { Generated Tons of } \\
\mathrm{CO}_{2} \text {-Equivalent }\end{array}$ & Are Included on GHG Calculation \\
\hline \multicolumn{3}{|l|}{ Granular layers (materials) } & \multirow{3}{*}{$\begin{array}{l}\text { MATERIALS PRODUCTION: drilling for } \\
\text { explosives for stones production; explosives } \\
\text { usage; stones transportation to milling facility; } \\
\text { stones milling and screening/classification; } \\
\text { TRANSPORTATION: stones from the milling } \\
\text { facility to the construction site; water from the } \\
\text { source to the construction site; UNBOUNDED } \\
\text { LAYER CONSTRUCTION: materials } \\
\text { spreading/paver; roller working time. }\end{array}$} \\
\hline Quantity of stone materials: & $144.10 \mathrm{~m}^{3}$ & & \\
\hline $\begin{array}{l}\text { Stone milling facility to site } \\
\text { average distance: }\end{array}$ & $64.60 \mathrm{~km}$ & 6.23 & \\
\hline \multicolumn{3}{|l|}{ Earthwork + grit surfacing } & \multirow{3}{*}{$\begin{array}{l}\text { MATERIALS EXTRACTION: soil/grit } \\
\text { excavation and loading. } \\
\text { TRANSPORTATION: soil from the } \\
\text { construction site to the stockpile place; grit } \\
\text { from the quarry to the construction site. }\end{array}$} \\
\hline Quantity of soil + grit: & $16382.40 \mathrm{~m}^{3}$ & & \\
\hline $\begin{array}{l}\text { Construction site to stockpile } \\
\text { place average distance: }\end{array}$ & $7.50 \mathrm{~km}$ & 36.32 & \\
\hline \multicolumn{3}{|l|}{ Site Preparation } & \multirow{4}{*}{$\begin{array}{l}\text { SITE CLEANING AND VEGETATION } \\
\text { REMOVAL: vegetation loading and transport } \\
\text { to the stockpiling place; superficial soil layer } \\
\text { loading and transport to the stockpiling place. }\end{array}$} \\
\hline Surface to be sanitized: & $3843.60 \mathrm{~m}^{2}$ & \multirow{3}{*}{0.55} & \\
\hline Soil thickness to be removed: & $0.30 \mathrm{~m}$ & & \\
\hline $\begin{array}{l}\text { Construction site to } \\
\text { stockpile distance: }\end{array}$ & $0.20 \mathrm{~km}$ & & \\
\hline \multicolumn{3}{|c|}{ Transportation, Vehicles and Machinery } & \multirow{16}{*}{ Fuel consumption } \\
\hline Transport of grass (Light truc & & 0.73 & \\
\hline $\begin{array}{l}\text { Transport of Vetiveria zizanio } \\
\text { (Middle truck) }\end{array}$ & des and grass & 3.85 & \\
\hline Transport of culverts (Middle & ruck) & 5.86 & \\
\hline Transport of large culverts (L & ge truck) & 0.54 & \\
\hline Transport of bush (Middle tru & & 1.35 & \\
\hline Transport of paver (Middle tr & & 14.96 & \\
\hline \multicolumn{2}{|c|}{ Transport of sand (Middle truck) } & 4.66 & \\
\hline \multicolumn{2}{|c|}{ Transport of steel (Middle truck) } & 0.33 & \\
\hline \multicolumn{2}{|c|}{ Bulldozer operation } & 1.96 & \\
\hline \multicolumn{2}{|l|}{ Motor grader operation } & 22.37 & \\
\hline \multicolumn{2}{|l|}{ Compactor operation } & 10.81 & \\
\hline \multicolumn{2}{|l|}{ Excavator operation } & 36.79 & \\
\hline \multicolumn{2}{|l|}{ Crane operation } & 1.05 & \\
\hline \multicolumn{2}{|l|}{ Buses } & 29.30 & \\
\hline \multicolumn{2}{|c|}{ TOTAL GENERATED $\mathrm{CO}_{2}$-Equivalent } & 177.66 tons & \\
\hline
\end{tabular}

\section{GHG Generated by the Regular Road Traffic}

The GHG due the traffic was calculated using CarbonROAD for a period of 10 years, an average trip length of $14.8 \mathrm{~km}$ and traffic rising rate of $3 \%$ a year, according to the information available on the engineering plans. As shown in Table 2, the generated GHG for the period is 398.31 tons, or a yearly average of 39.83 tons. It is a relatively small quantity, but the main purpose here is work on a small 
scale project in order to develop simplified engineering design methodology for low volume rural roads where the GHG assessment and compensation is included.

Table 2. GHG emission due the road operation for a 10 year period.

\begin{tabular}{cccc}
\hline Vehicle Type & Fuel & Number of Vehicles (10 Years) & $\begin{array}{c}\text { Generated GHG } \\
\text { (Tons of } \text { CO }_{2} \text {-Equivalent) }\end{array}$ \\
\hline Motorcycles & Gasoline & 8369 & 6.35 \\
Cars & Gasoline & 48,956 & 135.06 \\
Cars & Ethanol & 5440 & 5.90 \\
Small trucks & Diesel & 8369 & 62.99 \\
Light trucks & Diesel & 8369 & 112.44 \\
Middle trucks & Diesel & 4184 & 75.56 \\
Total & & 83,686 & 398.31 \\
\hline
\end{tabular}

\section{GHG Mitigation}

On the Santa Rosa de Lima project, the emission mitigation and compensation is done by the usage of vegetal protection for exposed land due the earthworks or due natural factors, as well as additional vegetation for slope protection and scenic beautifying. This particular project is prone to landslides close to the river shores; the stabilization with vegetation is part of the overall strategy.

The selected vegetal species are:

- $\quad$ Euterpe Edulis: It is a native specie on the project area and able to absorb $300 \mathrm{~kg}$ of $\mathrm{CO}_{2}$ until it is fully grown, according to the Secretaria de Estado do Meio Ambiente e Recursos Hidricos do Paraná [6]. After full growth, Euterpe Edulis is able to absorb $5.5 \mathrm{~kg}$ of $\mathrm{CO}_{2}$ per tree per year, according Ribeiro [7].

- Native grass: Studies done by Moreno [8] shows that is has the ability to absorb 85 tons of $\mathrm{CO}_{2}$ per year per hectare, being 80 tons fixed on the soil and 5 tons aerial.

- Vetiveria zizanioides: It has the ability to absorb $5 \mathrm{~kg}$ of $\mathrm{CO}_{2}$ per year per plant, fixed on the soil, according Ramalho [9].

The quoted $\mathrm{CO}_{2}$ capturing quantities are suitable for Brazil and may have important changes due the soil, climate and other variables.

The selected vegetal species are shown on Figure 6 and on the Table 3 is shown the quantities of each vegetal species and the total $\mathrm{CO}_{2}$ yearly capture.

Table 3. Vegetal species quantities and GHG capture per year.

\begin{tabular}{cccc}
\hline Specie & Quantity & $\mathbf{C O}_{2}$ Capture & Total $\mathbf{C O}_{2}$ Capture (Tons/Year) \\
\hline Euterpe Edulis & 1002 units & 0.0055 tons/tree/year & 5.5 \\
Native grass & 0.6735 hectare & 85 tons/hectare/year & 57.2 \\
Vetiveria zizanioides & 23,812 units & 0.005 tons/tree/year & 119.0 \\
& & Total & 181.7 \\
\hline
\end{tabular}




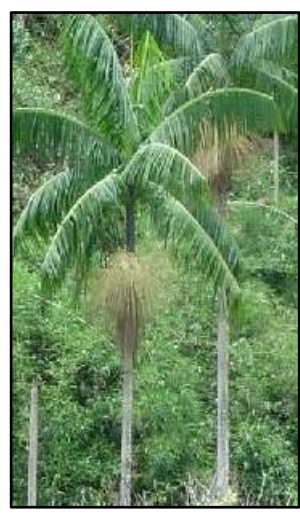

Euterpe Edulis

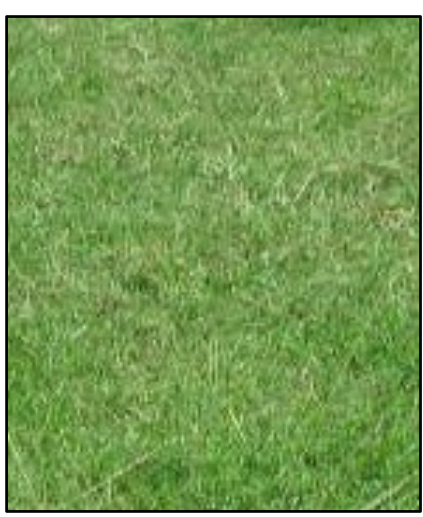

Native grass

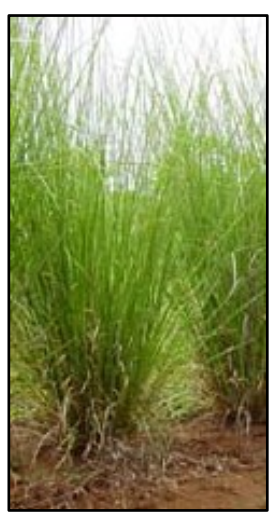

Vetiveria zizanioides

Figure 6. Species used for vegetal protection and emission compensation.

It can be seen in Figure 7 that after about 1 year and 3 months the absorbed $\mathrm{CO}_{2}$ quantity pass over the generated one. The year zero is when the emission due the road works happens; starting at year one, the traffic emission is added.

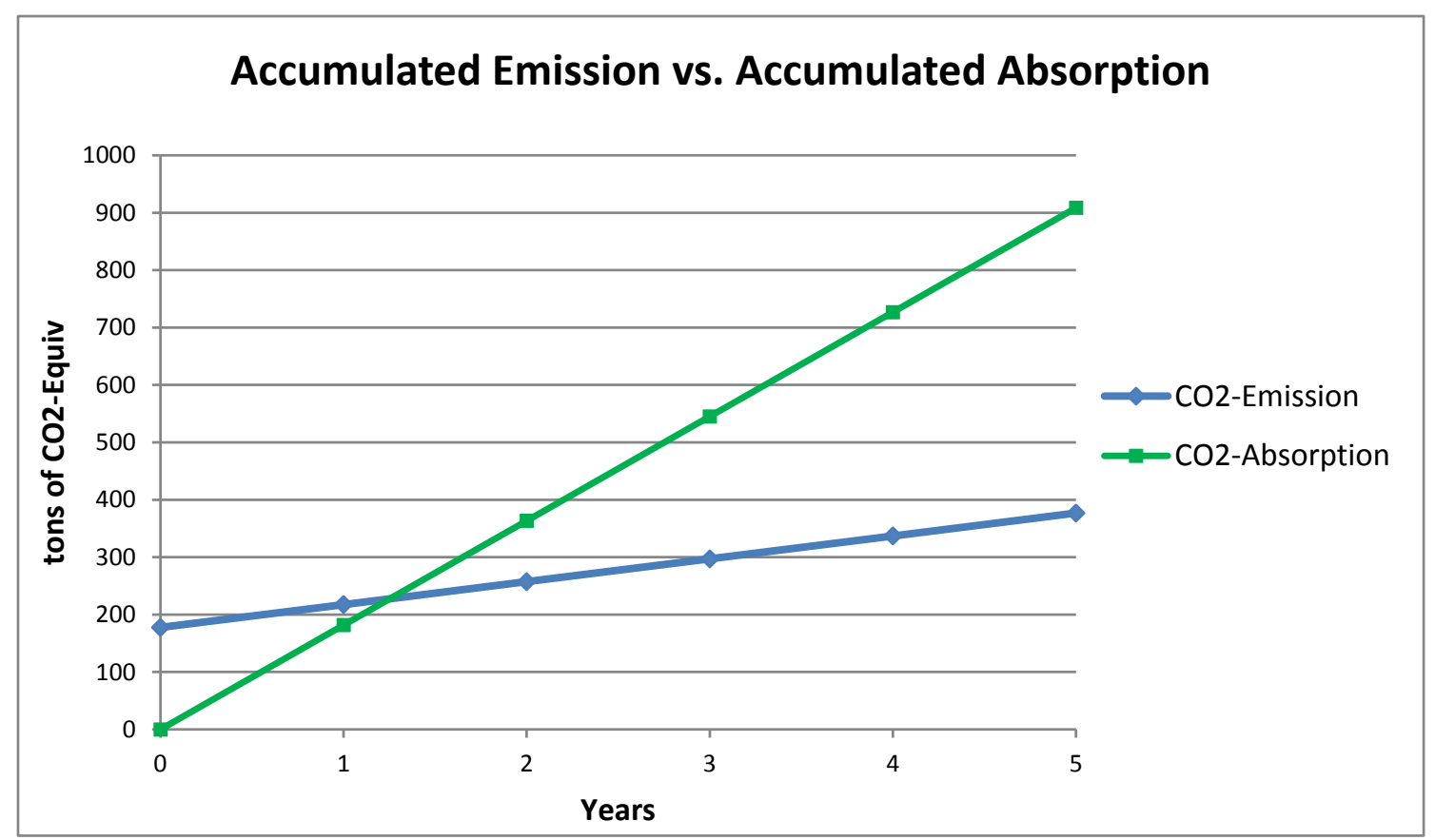

Figure 7. GHG emission balance.

\section{Monetizing the Absorbed Carbon Dioxide}

The Kyoto Protocol introduced the clean development mechanism and the emission trading for the carbon avoided, removed or sequestered through the carbon credits.

The market price for the carbon credits changes freely according the supply and demand. According the Brazil Carbon Institute [10] the carbon credit price on November 2013 was around 4.80 EUR per ton, but had prices over 15 EUR on the previous years.

For the Santa Rosa de Lima project, with $14.85 \mathrm{~km}$ and looking over a 30-year long period, the $\mathrm{CO}_{2}$ balance (absorbed less emission) is 4078.44 ton, i.e., 274.6 tons of $\mathrm{CO}_{2}$ per $\mathrm{km}$. Considering a carbon 
credit average price of 10.00 euro this means a value around 2746 EUR per km; it represents about $16 \%$ of the roads improvement costs for the same length.

The generated carbon credits can be used to pay back part of the World Bank loan or to construct other public infrastructures for the population on the project area. For the whole "Santa Catarina Rural" Program, with $1300 \mathrm{~km}$ of low volume rural roads, it represents a potential monetizing of 3.5 million euro.

\section{Conclusions}

Most of the emissions due the road works are related to fuel consumption. Machinery operation is the construction activity with the largest emission.

The correct infrastructure design and working plans facilitates the calculation of emission compensation on rural roads. For the Santa Rosa de Lima project the GHG plant absorption pass over emissions after just 1.25 years.

The positive carbon balance can be a suitable and efficient way to pay back part of the funds used to improve low volume rural roads; for the Santa Rosa de Lima project it represents $16 \%$ of the investment on the roads. The World Bank as well as other international banks may consider including this method of assessing sustainability as a standard practice for this kind of loan.

Emission assessment for works on rural roads projects can be successfully done by CarbonROAD software.

The government promoted standards with normalized emission values and harmonized calculation procedures will be required in the future to keep the GHG assessment consistence among the studies done by different actors including software developers.

\section{Acknowledgements}

We would like to thank the Santa Catarina State Government, The World Bank, APPE and Svevia companies for the support, and the assistance provided by the Municipality of Santa Rosa de Lima staff on the different phases of this project.

\section{Author Contributions}

Reus Salini worked on the CarbonROAD development, the field data collection, road improvement design, carried out the carbon emissions calculation and drafted the initial manuscript. Carl Anders Lenngren had the original idea to develop CarbonROAD, worked in its funding and development, the emission calculation review and paper improvements. Lauro Bassi worked on the field data collection, the environmental analysis, mitigation and compensation, and was responsible for the carbon absorption calculation. Dalcio Pickler Baesso was responsible for the Santa Rosa de Lima project management and review of field data collection and improvement designs. All the authors revised the manuscript and approved its final version.

\section{Conflicts of Interest}

The authors declare no conflict of interest. 


\section{Reference}

1. Environmental Protection Agency. Office of Transportation and Air Quality. 2011. Available online: http://www.epa.gov/oms/climate/420f05001.htm (accessed on 30 August 2011).

2. Chehovits, J.; Galehouse, L. Energy usage and greenhouse gas emissions of pavement preservation processes for asphalt concrete pavements. In Proceedings of the 1st International Conference of Pavement Preservation, Newport Beach, CA, USA, 13 April 2010.

3. Chappat, M.; Bilal, J. The Environmental Road of the Future: Life Cycle Analysis, Energy Consumption and Greenhouse. 2013. Available online: http://www.colas.co.uk/about-colasdetail.asp?pageId=14 (accessed on 22 August 2011).

4. Miljöstyrningsrådet. The Swedish Environmental Management Council. 2013. Available online: http://www.msr.se/en/ (accessed on 31 October 2013).

5. NCC Construction Sverige AB. The Swedish Construction Sector's Initiative: Developing of the Sector's Standard for Reporting of $\mathrm{CO}_{2}$ in Civil Engineering Projects; Internal presentation (09 SEP 2013); NCC: Stockholm, Sweden, 2013.

6. SEMA do Paraná. Entendendo Mudanças Climáticas. 2007. Available online: www.pr.gov.br/meioambiente/forumpr.shtml (accessed on 17 August 2012).

7. Ribeiro, S.C.; Jacovine, L.A.G.; Soares, C.P.B.; Martins, S.V.; de Souza, A.L.; Nardelli, A.M.B. Quantificação de biomassa e estimativa de estoque de carbono em uma floresta madura no município de Viçosa, Minas Gerais. Rev. Árvore 2009, 33, 917-926.

8. Moreno, J.M.; Castagna, A.A.; Neto, G.P.M.; de Seixas Filho, J.T.; de Souza, S.O.; Rodrigues, E.; Bretas, A.; Dilly, R.L. Sequestro de Carbono em Dois Sistemas de Pastoreio Rotativo. PESAGRO-RIO. Available online: http://www.pesagro.rj.gov.br/downloads/riorural/ 09\%20UPP\%20Sequestro\%20de\%20carbono.pdf (accessed on 31 December 2011).

9. Ramalho. Vetiver (Vetiveria Zizanioides). 2010. Available online: http://www.ramalho1.com.br/ public/files/attachments/6ea46424db5750b10bfbbbfc7a9f80f8.pdf (accessed on 24 August 2012).

10. Instituto Carbono Brasil. Conselho Europeu Aprova Medida de Retenção para Elevar Preço do Crédito de Carbono. 2013. Available online: http://www.institutocarbonobrasil.org.br/ mercado_de_carbono1/noticia=735633 (accessed on 8 November 2011).

(C) 2015 by the authors; licensee MDPI, Basel, Switzerland. This article is an open access article distributed under the terms and conditions of the Creative Commons Attribution license (http://creativecommons.org/licenses/by/4.0/). 